\title{
Radiobiological Targeting Role in Precision Radiation Medicine
}

\author{
Fawzi Abuhijla*, Fabio Moraes, Ramiz Abu-Hijlih, Pablo Munoz-Schuffenegger \\ Department of Radiation Oncology, Princess Margaret Cancer Centre, Canada
}

Submission: July 04, 2017; Published: July 06, 2017

*Corresponding author: Fawzi Abuhijla, Department of Radiation Oncology, Princess Margaret Cancer Centre, Toronto ON/Canada, Email: fawzi.abuhijla@rmp.uhn.ca

\section{Commentary}

Oncology precision medicine was developed in the last decades, utilizing new technology tools and genetics evolution to use more personalized decision making in patient diagnosis, treatment, and follow-up. Understanding the pathways for tumor growth, death resistance and spread [1] formed an opportunity in targeting these tracks to offer better tumor control, limit disease spread overcome treatment resistance. For allocating these pathways; genetics testing [2], functional and molecular imaging [3] provides various information to assist in this selection. The core of radiobiological targeting in personalized oncology is subgrouping patient according to specific genetic characteristics and biomarkers for individualized treatment instead of standardizing the treatment for patients with same anatomical tumor site no matter the difference in the molecular, functional or genetic testing [4].

Radiation therapy (RT) is considered major treatment modality for cancer which targets the DNA at the cancer cell level. Combining RT with selectively targeted agents based on personalized assessment result has the potential to improve outcomes by working on various targets enhancing the radiation sensitivity of tumor [5] or by working as radiation protector on normal tissue [6]. Different studies reported the effect of combining targeted agents with radiation therapy [7]. Challenges are that most targeted agent offer only limited inhibition of signaling pathway and many are very toxic to be used concurrently. Also, in vitro result does not always reflect in similar clinical outcomes, this could be related to tumor evolution and intra-tumor heterogeneity. Moreover, biomedical targeting research frequently requires high cost and a long time in to be established [8].
Smart selection of patients based on the genetics analysis for randomized clinical trials is the choice we have to continue on the right track. Having detailed discussions with our patients and their families about clinical trials including their rationale and expected effects to encourage further enrollment will keep the wheel running to provide future results for targeted agents in cancer therapy and, finally, lead to a better selection of RT volume, dose, and fractionation.

\section{References}

1. Hanahan D, RA Weinberg (2001) Hallmarks of cancer: the next generation. Cell 144(5): 646-674.

2. Yard BD, Adams DJ, Chie EK, Tamayo P, Battaglia JS, et al. (2016) A genetic basis for the variation in the vulnerability of cancer to DNA damage. Nat Commun 7: 11428.

3. Glunde K, Pathak AP, Bhujwalla ZM (2007) Molecular-functional imaging of cancer: to image and imagine. Trends Mol Med 13(7): 287297.

4. Baumann M (2016) Radiation oncology in the era of precision medicine. Nat Rev Cancer 16(4): 234-249.

5. Toustrup K (2011) Development of a hypoxia gene expression classifier with predictive impact for hypoxic modification of radiotherapy in head and neck cancer. Cancer Res 71(17): 5923-5931.

6. Athanassiou H (2003) Protective effect of amifostine during fractionated radiotherapy in patients with pelvic carcinomas: results of a randomized trial. Int J Radiat Oncol Biol Phys 56(4): 1154-1160.

7. Bentzen SM, PM Harari, J Bernier (2007) Exploitable mechanisms for combining drugs with radiation: concepts, achievements and future directions. Nat Clin Pract Oncol 4(3): 172-180.

8. Tannock IF, JA Hickman (2016) Limits to Personalized Cancer Medicine. N Engl J Med 375(13): 1289-1294. 
This work is licensed under Creative Commons Attribution 4.0 Licens

DOI: 10.19080/OAJS.2017.04.555650

\section{Your next submission with Juniper Publishers will reach you the below assets}

- Quality Editorial service

- Swift Peer Review

- Reprints availability

- E-prints Service

- Manuscript Podcast for convenient understanding

- Global attainment for your research

- Manuscript accessibility in different formats ( Pdf, E-pub, Full Text, Audio)

- Unceasing customer service

Track the below URL for one-step submission https://juniperpublishers.com/online-submission.php 